\title{
Professional Expectations of Sport Management Students as Related to Academic Curricular Alignment Support and Preparation
}

\author{
Steve Chen ${ }^{1}$, Heather Adams-Blair, ${ }^{2, *}$, Adora Miller ${ }^{1}$ \\ ${ }^{1}$ College of Business and Public Affairs, Morehead State University, Morehead, KY 40351, United States \\ ${ }^{2}$ College of Health Sciences, Eastern Kentucky University, Richmond, KY 40475, United States \\ *Corresponding Author: s.chen@moreheadstate.edu
}

Copyright $(2013$ Horizon Research Publishing All rights reserved.

\begin{abstract}
This study investigated the academic and career interest of 221 sport management students from two regional state institutions. The goal was to identify those students' needs and wants in order to properly guide and advise them obtaining a career in sports. Participants completed a 43-items survey questionnaire that was created based on the literature of Lewis and Quarterman (2006) and others. The contents covered: (a) demographic information, (b) career and sport interest, (c) sport spectatorial habits, (d) preferable work setting, (e) preferable cultivated skills/knowledge, and (f) self-perceived traits. Reliability analysis and test-retest were performed to test all 4-point Likert-scale rating items. The results show students are more interested in working for the professional franchises or intercollegiate athletics and desire to learn more communication and marketing skills. According to the stepwise regression analysis, both "preferable cultivated skills/knowledge" and "love for sports" are great predictors of one's rating in preferable sport career. The findings generally supported that notion that sport jobs are commonly filled by sport lovers and enthusiasts. The results also intrigue the researchers to address issues such as: the lack of diverse perspective and global awareness on the career choices, and recruitment and development of future female students.
\end{abstract}

Keywords Sport Management Education, Sport Career

\section{Introduction}

In early 2000, sport industry became one of the top 10 industries in America. It is estimated that the industry generates about $\$ 213$ billion dollars annually $[1,2]$. The popular of prime-time sport competitions and events certainly inspires more young people to dream about "being a part of a team" and "working for the dream jobs in professional leagues"[3]. As professional and recreational sports get more popular each day, many young prospects are attracted by this wealthy and rising industry and desire to seek a career in sport professions. Based on brochure information in 2005, Sportscareers.com indicated there were about 20-million sport jobs in 45 fragmental industries, with $11 \%$ being in ticket sales. Sportsearchonline.com also showed 4.5 million sports related jobs were in sport administration. Those jobs covered segments such as amateur athletics (11\%), corporate/sport marketing (35\%), facility and venue management (27\%), sporting goods $(21 \%)$, and teams, leagues and governing bodies $(6 \%)$.

Scholars had attempted to categorize those abundant numbers of jobs into several sectors. In general, career areas in sport industries may include the following sectors: athlete services (i.e., sport agents, financial services, and marketing), sport teams (i.e., professional, college, and high school), leagues\& associations (i.e, NASCAR, and PBA), sports media and communication, corporate sports marketing (i.e, $P \& G$ and Anheuser Busch), sporting goods manufacturers, facilities management (i.e., AEG and Comcast), and other [4-6].

The growth of the nation's sport management education programs has increased rapidly during the last 40 years [7]. In 2003, there were 233 sport management programs listed in the North American Society for Sport Management (NASSM) website, which represented an average growth of six new academic programs annually [8].Today, that list of colleges and university has increased to 426 . No wonder Parkhouse and Pitts [9] even claimed that sport management programs are the fastest growing discipline on college campuses. Individuals who wish to pursue a sport industry career are recommended to enroll in a sport management program. This academic program provides individuals with a thorough understanding of sports, business/management, and significant and meaningful practical work experiences relating to sport organizations/events management $[8$, 10].The popularity of the sport management was well 
illustrated bya 44 percent enrollment increase at the University of Missouri after adding the sports management emphasis program to its existing tourism program [11]. According to the US Bureau of Labor Statistics, it was estimated about 8,517 American students graduated with sports management degrees in 2010. Many of those individual would join the existing $1,722,470$ sports managers in the work force [12].

\section{Literature Review}

As more schools and programs provide the educational training to breed the future prospects entering the sports business field, there are more ethical and moral responsibilities placed on the institutions to provide high quality and adequate education for their students [13]. The NASSM and the National Association for Sport and Physical Education (NASPE) are examples of academic organizations that help set the standards for the sport management education. In the past, those organizations have played the role of governing body to establish the guidelines and key elements of a sport management curriculum [14]. Overall, academicians agreed that the curricula approved by the NASPE -NASSM reviewing committee should help students prepare for the sport industry well. Their approval on the curricular standards was also reflective of the competencies needed for students to work in the sport industry $[8,15]$. According to the approval standards of NASSM and NASPE [14], mandatory course content of a program include 10 areas: (a) sociocultural dimensions in sport, (b) management and leadership, (c) ethics in sport management, (d) marketing in sport, (e) communication in sport, (f) budget and finance in sport, (g) legal aspects in sport, (h) economics in sport, (i) governance in sport, and (j) field experience.

Today, the ideal content of a modern sport management program is not much different from that approval list. The following courses are common additions on top of that list: (a) Sport Labor Relations, (b) Structure of Sport Industry, (c) Facility Maintenance and Planning Management, de) Event Management, (e) Contemporary Issues in Sport Management, and (k) Sport Management Research Methods [16-17]. According to Parks, Quarterman, \&Thibault [5]., an individual who wishes to become a high quality sport industry professional must emphasize four specific traits beside taking the required courses: (a) image and appearance, (b) work ethic, (c) job and communication skills, and (d) teamwork ability.

Since more sport jobs were available in the marketing and sales of professional teams and recreational sport sector, Newtrackindia.com [18] further recommends training in the following areas: (a) sponsorship and promotion in sport, (b) recreation and fitness courses, (c) press communication as well as the media and broadcasting, (d) sports regulation on contracts and drug use. Lists and recommendations of top skills and qualities sought in new college hires may include: (a) communication skills, (b) computer skills, (c) strong work ethic, (d) interpersonal skills, (e) honesty, (f) planning skills, (g) leadership skills, (h) diversity and global awareness, (i) flexibility, (j) creativity, (k) professionalism, and (1) foreign language skills, etc. [19-21]. Although some of the suggestions and advice may seem to be basic and redundant, they are all practical and effective advice that many students may ignore or neglect to follow.

Each year, the Street and Smith's Sports Business Journal selects the top 40 young promising and exemplary sport industry leaders and recognizes their accomplishments and contributions. Ideally, the traits and background of these successful professionals are areas of interests for business scholars to analyze. While observing the profiles of those renowned candidates during the last four years [22-25], some interesting conclusions can be drawn: (a) A very high majority of the winners are White males (over 86\%); (b) at least $55 \%$ of the winners have a business related degree, $20 \%$ may have a law degree, $40 \%$ have a graduate degree, and yet only $10 \%$ have a sport management degree, (c) over $80 \%$ of the winners were either high school or college athletes, (d) many of the winners were willing to take a job outside the United States (over $80 \%$ ) and at least $10 \%$ of them are fluent in a second language, and (e) at least half of them started their careers in sports and nearly two thirds of them are sport event attenders (unrelated to their work).

Many studies focus on required and appropriate academic courses and preparation for the sport management program [17, 26-28]. Moreover, many discussions would center on the approval process and the standards that were set up by NASPE and NASSM or the most appropriate academic discipline (colleges or schools) for hosting the sport management programs $[8,15]$. The consensus conclusions are that programs hosted under the college of business or sport sciences are best tailored for delivering a quality program. However, less research delved into the students' expectations and perceptions about their learning experience in the sport management program. The study of Lewis and Quarterman [29]was one of the few existing studies that examined the relative importance of choice factors for students enrolling in the field of sport management for a master's degree. Based on the 194 completed responses, the three most important reasons for returning for a master's degree in sport management were "I enjoy athletics", "I enjoy being in an athletics setting" and I desire to know more about the sport business."

Recently, Schwab and colleagues [30] conducted a study to better understand sport management students within departments of parks, recreation, and tourism. Their goal was to address the uneasy fit that faculty may experience when putting sport and recreation students in the same classes. Based on 1,337 sport management undergraduates' responses, it was clear that many students were highly identified with sport rather than recreation. Many are highly focused on a career in sport and neglect recreation as an option. They further concluded recommendations for 
advising and curriculum planning to help students recognize the employment potential.

\section{Objectives}

This study investigated the perceptions and expectations of sport management students from two regional state universities in eastern Kentucky. The researchers attempted to compare the collected student responses with existing information relating to recommended professional skills, training, and educational experience for future sports professionals. The findings can be used to identify the needs of the students and further align the current pedagogy to support students effectively. The researchers assumed, with the unique student perspectives and the regional geographic condition, the findings can provide recommendations for improving instruction and advising tips that ensure students cultivate desired skills/knowledge for obtaining a sport profession.

\section{Methods}

\subsection{Participants and Procedure}

The participants of this study included 221 students (181 males, $82 \%$; 39 females, $18 \%, 1$ misidentification) who were enrolled in several sport management courses offered by two regional state universities in eastern Kentucky. Before responding to the survey, the researchers informed all participants about their right for completing the survey and the possibility of earning extra credits for their participation. More than $95 \%$ of the students on the course rosters completed the survey. The information was collected during the first three class meetings of the 2012 fall semester. Table 1 exhibits the breakdown of the demographic information of the participants.

\subsection{Instrumentation}

The survey questionnaire of this study contains a total of 43 items. It covered six content areas such as: (1) personal academic and sport interest, (2) sport spectatorial habit, (3) preferable sport career, (4) preferable work setting, (5) desirable cultivated skills/knowledge, and (6) self-perceived traits. Along with those six areas, a section of demographic questions was also contained in the survey. Each of the areas was further validated through factor analyses as shown in Table 2. There were a total 38 4-point Likert Scale items for the participants to complete. The number of each rating stands for the level of agreement to a listed statement ( 1 = weak, 2 = moderately strong, $3=$ strong, $4=$ very strong). The question items were created after reviewing the concepts of several past studies and articles [3, 15, 17, 29]. A pilot group consisted of 32 students engaged in the test-retest procedure to examine the reliability of the question items. The Pearson correlation value between the two tests exceeded .780 .

\section{Results}

The factor analysis categorized the non-demographic question items $(n=39)$ into nine constructs. Table 2 listed the name and rating of each construct. In general, the participants exhibited a fairly high score $(\mathrm{M}=3.70$ on a 5-point scale) in "love for sports." Clearly, the participants also favored professional franchises and institutional organizations more than any other options as preferable work settings. As Lewis and Quarterman [29] mentioned, graduate students simply chose sport management as their study because they loved athletics and enjoyed to work in an athletic setting. It seems the undergraduate participants of this study also show the similar tendency. The finding of this study was coincided with the conclusion of Schwab and colleagues as well [30]. Sport management students indeed are more identified with the career choices in sport areas rather than the recreational component.

Additional descriptive analyses identified the participants' top responses on perceived professional traits and career aspiration. For example, top-3 preferable work settings were (a) professional franchises/organizations, (b) intercollegiate and interscholastic athletics, and (c) privately owned companies. Most desirable skills/knowledge that participants sought to develop were: (a) communication skills, (b) marketing skills, and (c) knowledge in legal aspects. Both communication and marketing skills are recognized as top essential skills of achieving a successful career in sport industries [18-20]. Participants' top-3 preferable sport career choices were: (a) administration, (b) facility and event management, and (c) sales/marketing. These three choices were all part of as the top-4 major career segments according to Sportsearchonline.com.

Participants' personal interest in sport career aspiration and perceived professional traits varied significantly based on a couple of demographic variables such as gender and academic major. As the results suggest, males' ratings are greater than females' ratings in love for sports, sport spectatorial habit, and adventurous spirit \& professional traits. Sport Management students' rating are greater than those of non-sport management major in sport spectatorial habit, preferable sport career, love for sports and desirable cultivated skills/ knowledge.

The correlation analysis indicates that participants' academic and career interests are correlated with several factors such as love for sports, preferable work setting, desirable cultivated skills/knowledge, and adventurous spirit \& professional traits. However, the strengths of correlation are all at moderate level (values of Pearson $r$ range from .29 to .481 )

Furthermore, participants' preferable sport career can be best predicted by two constructs as well, which are "desirable cultivated skills/knowledge" and "love for sports." Overall, the participants' academic and career interest can be best predicted by two constructs: (a) preferable work setting, and (b) love for sports. 
Table 1. Class level and major of the participants (181 males, 39 females, \& 1 missing case)

\begin{tabular}{|c|c|c|c|c|c|c|}
\hline \multirow{2}{*}{ Category } & \multicolumn{3}{|c|}{ Class Level } & \multicolumn{3}{c|}{ Major } \\
& \multicolumn{2}{|c|}{ Fr. } & \multicolumn{2}{c|}{ Soph. } & Jr. \& Grad Student & \multicolumn{2}{c|}{ Yes } \\
\hline Institution No. & 24 & 27 & 30 & 37 & 98 & 23 \\
$(\mathrm{n}=121)^{*}$ & $(19.8 \%)$ & $(22.3 \%)$ & $(24.85)$ & $(30.6 \%)$ & $(81.0 \%)$ & $(29 \%)$ \\
\hline Institution No. & 3 & 11 & 37 & 49 & 86 & 14 \\
$(\mathrm{n}=100)$ & $(3.0 \%)$ & $(11.0 \%)$ & $(37.0 \%)$ & $(49.0 \%)$ & $(86.0 \%)$ & $(14.0 \%)$ \\
\hline
\end{tabular}

*3 missing cases for class level in Institution No. 1

Table 2. Results of the factor analyses on nice constructs (38 total items on a 4-point scale)

\begin{tabular}{|c|c|c|c|}
\hline Content Areas and Their Construct & Reliability coefficient (Cronbach's $\alpha$ ) & Factor loading $(\%)$ & Average rating \\
\hline Area 1. Personal academic and sport interest & .708 & 66.6 & \\
\hline $\begin{array}{l}\text { a. Academic and career interest ( } 2 \text { items }) \\
\text { *interest in sport management program } \\
\text { *like to pursue a sport profession }\end{array}$ & & & 3.55 \\
\hline $\begin{array}{l}\text { b. Love for sports ( } 3 \text { items) } \\
\text { *love to attend sport events } \\
\text { *love to be a spectator } \\
\text { *love to play }\end{array}$ & & & 3.70 \\
\hline Area 2. Sport spectatorial habit & .723 & 56.6 & \\
\hline $\begin{array}{l}\text { c. Sport spectatorial habit ( } 5 \text { items) } \\
\text { *watching games/competitions, watching sport } \\
\text { movies, watching talk shows, watching } \\
\text { documentaries, watching sport news }\end{array}$ & & & 3.40 \\
\hline Area 3. Preferable sport career & .728 & 42.8 & \\
\hline $\begin{array}{l}\text { d. Preferable sport career ( } 6 \text { items) } \\
\text { *sporting goods, administration, sport agent, media, } \\
\text { sales/marketing, and facility/event management }\end{array}$ & & & 2.77 \\
\hline Area 4. Preferable work setting & .625 & 55.6 & \\
\hline $\begin{array}{l}\text { e. Professional \& Institutional Franchises ( } 4 \text { items) } \\
* \text { Schools and professional franchises/leagues }\end{array}$ & & & 3.41 \\
\hline $\begin{array}{l}\text { f. Others ( } 2 \text { items) } \\
\text { *recreation center, independent agency, non-profit } \\
\text { organizations, private/corporate business }\end{array}$ & & & 2.42 \\
\hline Area 5. Desirable cultivated skills/knowledge & .831 & 49.8 & \\
\hline $\begin{array}{l}\text { g. Desirable cultivated skills/knowledge ( } 7 \text { items) } \\
\text { *marketing, finance, computer, communication, legal } \\
\text { aspects, human resources management, information } \\
\text { technology }\end{array}$ & & & 2.95 \\
\hline Area 6. Self-Perceived Traits & .811 & $53.7 \%$ & \\
\hline $\begin{array}{l}\text { h. Adventurous spirit \& professional traits (5 items) } \\
\text { *working in a foreign country } \\
\text { *enjoying volunteering work } \\
\text { *working long hours } \\
\text { *working on weekends } \\
\text { *willing to relocate }\end{array}$ & & & 2.90 \\
\hline $\begin{array}{l}\text { i. Communication and personality ( } 4 \text { items) } \\
\text { *able to communicate well } \\
\text { * complete assigned task } \\
\text { *people oriented } \\
\text { *outgoing personality }\end{array}$ & & & 3.37 \\
\hline
\end{tabular}




\section{Discussion}

Since participants' interest toward academic program and career interest can be best predicted by desirable cultivated content knowledge and love for sports, it is logical to conclude that participants' passion for sports and desire to learn are strong motivators that keep them pursuing a career in sport industries. This finding supports a common trend identified in the literature review that sport jobs are commonly filled by sport lovers and enthusiasts [5, 29]. An interesting question that has arisen from the results is whether "love for sports" is an essential criterion to work in the sport industry. In order to overcome shortcomings such as excessively long work hours during the weekend and relatively low stipends at the entry level sport jobs, job candidates certainly must have strong passion and love for what he/she is doing. As in any other literature relating to employment and human resources [17, 19-20], communication is viewed as the most important skill recognized by scholars, professionals, and students as well. It is pleasing to witness students actually valued some of the skills (communication and marketing skills) that were emphasized by the scholars [17]. In addition to the common sport curricular courses, students must spend more time polishing writing and presentation skills.

The participants' rating on preferable sport career was moderately correlated with preferable developed content knowledge $(\mathrm{r}=.628, \mathrm{p}<.01)$. In another word, when participants valued each of the career choice highly, their view of importance on each of the preferable cultivated skill went higher. This finding reminds the educators of the impact emphasis and quality of educational training may have on the students. When students are better equipped with essential professional skills, they are eager to learn more and thus more determined to stay in the chosen career field. Although this sounds like a very rudimentary statement, it indeed illustrates the impact of high quality education that the program and instructors may bring to their students.

While the participants revealed their needs and expectation through their respective chosen field and sport preferences, the researchers believed special attention should be addressed to the students. There was excessive emphasis in professional franchises and institutional athletic departments in participants' responses. This result seems to reflect that participants have a pigeon-hole view of what sport industries are about, and a limited understanding about where potential job opportunities reside. This is the exact problem that Schwab and colleagues [30]observed as well. Students should understand that they will not learn enough about the sport industries by merely watching a lot of sport competitions and news on TV. In the meantime, the demographic data also showed the enrollment of female students in sport management program is evidently lower than the ratio of female students on campus. It this phenomenon holds true in all of the sport management programs, then it is not surprising that only a rare few ladies are selected as potential successful sport business leaders. There are not enough females in the sport industries as compared to other work forces to get promoted and advanced.

While examining the participants' response on the perceived personal traits, it was found that the rating of adventurous spirits and professional traits was relatively low among all constructs $(<3.00)$. In summary, they are not very fond of working long hours, traveling away for other opportunities or volunteering. Obviously, these traits are exactly opposite to those successful sport professionals (i.e., candidates of 40 under 40) have possessed. Faculty members may need to be more active to get students physically involved in volunteer works and traveling. Students must be aggressively encouraged to take internships or practicum experience outside of their home town or state.

\section{Conclusions}

Overall, this study helped identify a few program and curricular issues that faculty members should revolve with effort and consideration. Those issues included: (1) relatively low percentage of female enrollment of the program (less than 25\%); (2) excessive emphasis in professional and collegiate sports as a career choice; and (3) relatively low rating in certain personal traits and adventurous spirits. In order to improve and rectify the aforementioned issues, the researchers believe emphasis and focus should be placed on the following areas. When designing an academic curriculum for a sport management program, scholars and administrators must address following key points.

(1). Expanding diverse perspective and global awareness: This will help students learn about existing different job opportunities and broaden their skills sets. Since the researchers' institutions are located in the state of Kentucky, there are three regional prosperous sport and recreation industries that can be introduced to the students, such as horse racing (equine industry), motor racing (Kentucky Speedway), and trail hiking.

(2). Promoting service learning and engaging students in all types of volunteer works, civil services, and internships;

(3). Assessing students' career aptitude and interests systematically and periodically;

(4). Recruiting and fostering more future female students; and

(5). Lastly, promoting the use of social media to guide students as to how to showcase their relevant professional works and build their networks with other professionals. 


\section{REFERENCES}

[1] D. Broughton, J. Lee, R. Nethery. The answer: \$213 billion. Street \& Smith's SportsBusiness Journal, Vol. 2, No. 34, 23, 26, 1999.

[2] B.L. Parkhouse (Ed.), The Management of Sport: It's Foundation and Application (4th ed.), McGraw-Hill, New York, 2004.

[3] J. Shaw, Media's influence on career choice: Who is in control of our career path? Media or the individual, Online available from

http://suite101.com/article/medias-influence-on-career-choic es-a379318, 2013

[4] B. Rand, Sports management careers and salaries. Online Avai http://work.chron.com/sports-management-careers-salaries-7 873.html

[5] J. B., Parks, J. Quarterman, L. Thibault, Contemporary sport management (3rd. ed.). Human Kinetics, Champaign, IL, 2007.

[6] M. D. Shank, Shank, Sports marketing: A strategic perspective (4th ed.). Prentice Hall, Upper Saddle River, NJ, 2009.

[7] W. J. Weese, Opportunities and headaches: Dichotomous perspective on the current and future hiring realities in the sport management academy. Journal of Sport Management, Vol. 16, No. 1, 1-17, 2002.

[8] C. Laird, The influence of sport management program characteristics on academic perceptions of NASPE-NASSM approval. SMART Online Journal, Vol. 1, No. 2, 4-13, 2005

[9] B. L, Parkhouse, B. G. Pitts, B. G. (2004). History of sport management. In B.L. Parkhouse (Ed.), TheManagement of Sport: It's Foundation and Application (4th ed.) (pp. 2-14).McGraw-Hill, New York, 2004.

[10] NASSM, University-based sport management programs. Online available from http://www.nassm.org/universities.htm, 2003

[11] [Associated Press, Sports management drives Mizzou enrollment surge. Online available

fromhttp://www.stltoday.com/news/local/education/article_6 caa6e08-b459-11e0-9d30-001a4bcf6878.html, 2011

[12] Hack College, Sport management schools, Online available fromhttp://www.hackcollege.com/school-finder/schools/spor ts-management/

[13] J. T. DeSensi, D. Rosenberg, Ethics and morality in sport management (2nd ed.). Fitness Information Technology, Morgantown, WV, 2009.

[14] [NASPE-NASSM, Sport management program standards and review protocol. Online available from www.aapherd.org/naspe/template.cfm?template $=$ ns_smps.ht $\mathrm{ml}, 2000$

[15] A. N. Eagleman, E. L. McNary, What are we teaching our students? A descriptive examination of the current status of undergraduate sport management curricula in the United
States. Sport Management Education Journal, Vol. 4, No.1, $1-17,2010$

[16] Education Portal, Sports management adult education programs: An overview. Online available from

http://education-portal.com/articles/Sports_Management_Ad ult_Education_Programs\%3A_An_Overview.html, n.d.

[17] M. D. Kerr. Implementation of a sport management major within an undergraduate exercise and sport science department. The Sport

Journal, Vol.6, No. 2, Online available from http://www.thes portjournal.org/article/implementation-sport-management-m ajor-within-undergraduate-exercise-and-sport-science-depart, 2003

[18] Newstrackindia.com, Tips for landing a sport job. Online available from $\mathrm{http} / / /$ newtrackindia.com

[19] J. Cuneen, M. J., Sidwell, Sport management field experiences. Fitness Information Technology, Morgantown, WV, 2003.

[20] National Association of Colleges and Employers, Job outlook 2005. Online Available from www.naceweb.org/products/jo2 005report.htm

[21] V. Patterson, C. Allen, Occupational outlook overview: Where will the jobs be in 2005? Journal of Career Planning and Employment, Vol. 56, No. 3, 32-35, 61-64, 1996.

[22] Sports Business Journal, Forty under 40. Street \& Smith's Sports Business Journal, Vol. 12, No. 44, 1A-51A, 2010.

[23] Sports Business Journal, Forty under 40. Street \& Smith's Sports Business Journal, Vol. 13, No. 45, 1A-53A, 2011.

[24] Sports Business Journal, Forty under 40. Street \& Smith's Sports Business Journal, Vol. 14 No. 45, 1A-50A, 2012.

[25] Sports Business Journal, Forty under 40. Street \& Smith's Sports Business Journal, Vol. 15 No. 46, 1A-58A, 2013.

[26] J. Cuneen, Evaluating and selecting sport management undergraduate programs, Journal of College Admission, Vol. 158, 6-13, 1998.

[27] J. Cuneen, M. J. Sidwell, Graduate-level professional preparation for athletic directors. Journal of Sport Management, Vol. 6, No. 1, 15-26, 1992.

[28] B. Parkhouse, Sport management curricula: Current status and design implication for future development, Journal of Sport Management, Vol. 1, No. 2, 93-115, 1987.

[29] B. A. Lewis, J. Quarterman, Why students return for a master's degree in sport management. College Student Journal, Vol. 40, No. 4, Online available from http://www.freepatentsonline.com/article/College-Student-Jo urnal/156364404.html, 2006

[30] K.A. Schwab, D. Dustin, E. Legg, D. Timmerman, M.S. Wells, \& S. G. Authur-Banning. Choosing sport management as a college major, SCHOLE: A Journal of Leisure Study and Recreation Education, Vol. 28, No. 2, page. 2013 